Historic, Archive Document

Do not assume content reflects current scientific knowledge, policies, or practices. 

Hang This Card Up Forftitite Rerence

\section{RETAIL PRICE LIST OF}

\section{The Reed Nursery Co.} Hanover, Ind., R. F. D. No.I

W. H. REED Jr. \& C. N. REED, Proprietors

Price of Apple and Peach

Extra Select 6 to 7 feet, better than first class, 20 cents each, \$I8 per IoO.

First Class 5 to 6 feet, I 5 cents each, \$I 3 per IoJ. Four to five feet r 2 cents each, $\$$ Io per Ioo.

Three to four feet ro cents each, $\$ 8$ per roo. Twenty Trees at $\mathrm{I} 00$ rates.

Price of Pear, Cherry, Plum and Quince

Extra Select, 6 to 7 feet, better than first class, 50 cents each, $\$ 45$ per Ioo.

First Class, 5 to 6 feet, 40 cents each, $\$ 35$ per Ioo. Four to five feet, 30 cents each, $\$ 25$ per 100.

Three to four feet; 25 cents each, $\$ 20$ per IOO. Twenty Trees at $\mathrm{I} 00$ rates.

Mail us a list of your wants. 
